\title{
Drug-eluting coronary stents - focus on improved patient outcomes
}

This article was published in the following Dove Press journal:

Patient Related Outcome Measures

2I September 201 I

Number of times this article has been viewed

\author{
Zehra Jaffery \\ Amit Prasad \\ John H Lee \\ Christopher J White \\ Department of Cardiovascular \\ Diseases, The John Ochsner Heart \\ and Vascular Institute, Ochsner Clinic \\ Foundation, New Orleans, LA, USA
}

\begin{abstract}
The development of stent has been a major advance in the treatment of obstructive coronary artery disease since the introduction of balloon angioplasty. Subsequently, neointimal hyperplasia within the stent leading to in-stent restenosis emerged as a major obstacle in long-term success of percutaneous coronary intervention. Recent introduction of drug-eluting stents is a major breakthrough to tackle this problem. This review article summarizes stent technology, reviews progress of drug-eluting stents and discusses quality of life, patient satisfaction, and acceptability of percutaneous coronary intervention.

Keywords: drug-eluting stent, coronary intervention, patient outcomes
\end{abstract}

\section{Introduction}

Percutaneous transluminal coronary angioplasty (PTCA), introduced by Andreas Gruntzig in 1977, revolutionized coronary artery revascularization from open heart surgery to a percutaneous procedure. However, PTCA was limited by periprocedural complications including coronary dissection and vascular recoil resulting in emergent coronary occlusion, and a significant (30\%-50\%) incidence of recurrence or restenosis, which compromised long-term efficacy. ${ }^{1,2}$ The development of a scaffolding metal mesh tube called a "stent" that could be delivered on the balloon catheter improved both problems. The widespread adoption of bare metal stents (BMS) was hindered by two limitations: the risk of sudden occlusion due to stent thrombosis and a high $(30 \%-40 \%)$ incidence of in-stent restenosis (Figure 1). ${ }^{3}$ More aggressive dual antiplatelet therapy and high-pressure stent deployment dramatically lowered the risk of stent thrombosis and restenosis. ${ }^{4}$

Understanding the processes and mechanisms involved in in-stent restenosis was the key driver for the development of drug-eluting stent (DES) technology. In-stent restenosis is a result of a response to injury to the arterial wall, which triggers an inflammatory process resulting in proliferation and migration of smooth muscle cells from the arterial media. Exuberant neointimal growth, encroaching on the vessel lumen leads to in-stent restenosis. ${ }^{5,6}$ DES delivered antiproliferative and immunosuppressive drugs to the arterial wall, dramatically reducing in-stent restenosis and they have now become mainstream therapy for percutaneous coronary intervention (PCI).

\section{DES design}

The goal of stent design, in addition to deliverability and effective lesion scaffolding, is that the stent should minimize the neointimal host response and not be toxic. A DES consists of three components: a metal scaffold, the active pharmacological 


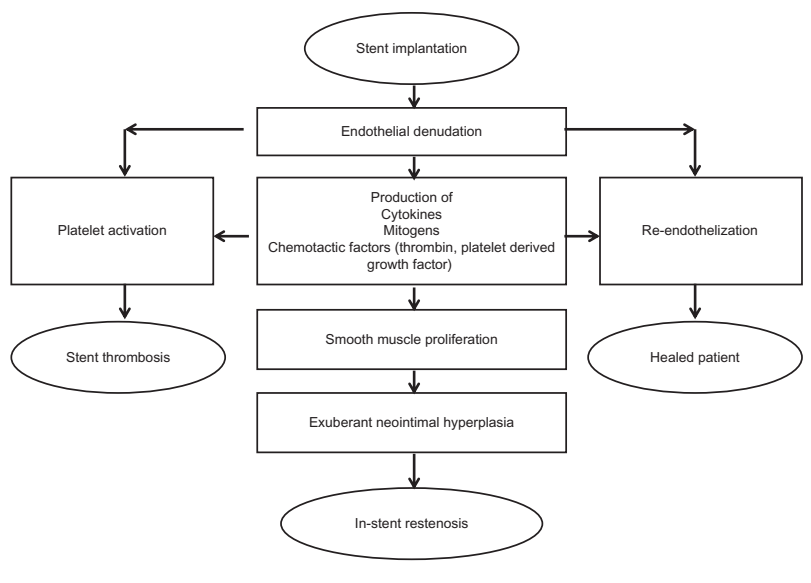

Figure I The response to stent implantation.

Reprinted from J Am Coll Cardiol, Vol. 56, Garg and Serruys, Coronary stents: current status, Pp. SI-S42, Copyright (2010), with permission from Elsevier. ${ }^{98}$

agent, and a carrier for the drug. The metal stent platform must be flexible enough for deliverability, radiopaque for visibility, biocompatible for long-term mechanical stability after implantation. Modern stents are made of stainless steel or cobalt chromium, and they vary in their strut pattern and length of radially expandable elements (Figure 2). ${ }^{7}$ There is an association between stent strut thickness and restenosis with thinner struts associated with less restenosis. ${ }^{8}$ Cobalt chromium exhibits superior radial strength and improved radiopacity when compared to stainless steel. This permits thinner stent struts for cobalt chromium stents and leads to a reduction in device profile, increasing the ease of stent deliverability to the target lesion. ${ }^{9}$ Other alternatives to a metallic stent platform, such as biodegradable and bioabsorbable stent platforms are also being explored. ${ }^{10}$

The metal stent backbone is coated with a thin polymer film containing the active drug, which is released in controlled
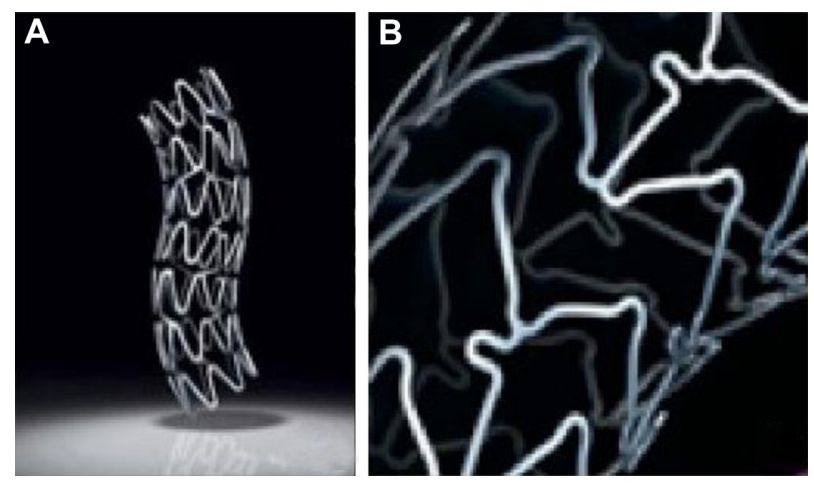

Figure 2 Coronary stents. (A) Taxus ${ }^{\circledR}$ stent (Boston Scientific Corporation, Natick, MA) with stainless steel metallic platform; (B) Xience $V^{\circledR}$ Everolimus Eluting Coronary Stent (Abbott Laboratories, Abbott Park, IL) with cobalt chromium platform. (C) 2011 Boston Scientific Corporation or its affiliates. All rights reserved. Used with permission of Boston Scientific Corporation. Reproduced with permission of Abbott Laboratories. amounts locally at the site of implantation. Wide ranges of polymers are available as carriers of the active drug. Polymers are classified as biodegradable, such as poly-L lactic acid, or nonbiodegradable (durable), such as polyurethane derivatives and silicone based polymers. ${ }^{11,12}$ Coatings have several engineering challenges of their own as they may crack, decompose, and dissolve over time. In addition, the biocompatibility of polymers used for coating stents is critical. Nonbiodegradable polymers have been implicated in delayed healing, impaired stent strut endothelization, and a hypersensitivity reaction which can contribute to stent thrombosis. ${ }^{13}$ The nonbiodegradable phosphorylcholine polymer used in the Endeavor ${ }^{\circledR}$ Sprint Zotarolimus-Eluting Coronary Stent System (Medtronic, Inc, Minneapolis, MN) releases 95\% of the sirolimus analog, zotarolimus, within 14 days of stent deployment; although nonbiodegradable it is biocompatible (a natural component of cell membrane), causing less inflammation compared with the polymers used on the Cypher ${ }^{\circledR}$ Stent (Cordis Corporation, Warren, NJ). ${ }^{14}$ Current research is looking into stents that will have novel coatings or are completely polymer free. ${ }^{15}$

\section{Pharmacology of DES}

Pharmacological agents incorporated on the stent surface prevent restenosis by interfering with the cell cycle in some way. For example, paclitaxel and sirolimus both have antiproliferative properties (inhibit proliferation of vascular smooth muscle and endothelial cells) and also have potent anti-inflammatory function and affect cell migration and motility. ${ }^{16,17}$ Compartmentalizing these agents as either antiproliferative or anti-inflammatory will understate the breadth of their biological activity. Below is a brief description of the mechanism of action of the current Food and Drug Administration-approved agents for coronary stent application: sirolimus, paclitaxel, zotarolimus, and everolimus.

Sirolimus, zotarolimus, and everolimus all interfere with the cell cycle in the presynthetic (G1) phase. Sirolimus (previously called rapamycin) is a natural macrolide antibiotic produced by the fungus Streptomyces hygrissopicus that is able to inhibit cytokine and growth factor mediated proliferation of lymphocytes and smooth muscle cells, resulting in reduced neointimal proliferation. ${ }^{18}$ Zotarolimus is a semisynthetic (made by substituting a tetrazole ring for the native hydroxyl group at position 42 in rapamycin) analog of sirolimus. ${ }^{19}$ Everolimus is a synthetic derivative of sirolimus (40-O-[2-hydroxyethyl]-rapamycin). ${ }^{20}$ Paclitaxel is an antineoplastic agent isolated from the bark of the Pacific Yew tree, Taxus brevifolia. It acts on the postsynthetic G2 phase, 
stabilizing microtubule assembly, thereby inhibiting mitosis of smooth muscle cell and inhibiting cell migration. ${ }^{17}$

\section{Pharmacokinetics of DES}

Pharmacokinetics is the mechanism through which a drug is absorbed, distributed, metabolized, and eliminated from the body. The pharmacokinetics of DES are determined by the drug's intrinsic properties and by the coating technique used in applying it on the stent platform. The physiochemical properties of the pharmacological agent used in a DES such as diffusivity, hydrophilic or hydrophobic nature, and presence or absence of protein binding are important considerations as these have an effect on the biological action of these agents. ${ }^{21,22}$

The drug reservoir (polymer and drug mixture) is covered with a thin polymer membrane which functions as a rate-controlling membrane allowing a constant amount of drug to be released over time resulting in zero-order kinetics (Figure 3). ${ }^{23}$ An example is the Cypher stent. The Cypher stent is designed to release $80 \%$ of total dose in 4 weeks and the rest over the course of the next 2 weeks. ${ }^{18}$ In a matrix design, a drug is usually dispersed inside the polymer matrix, and the drug is released into the environment without any rate-controlling barrier layer. Therefore, the amount of drug released over time varies, resulting in nonzero-order kinetics. ${ }^{23}$ An example is TAXUS ${ }^{\circledR}$ Express $^{2 \circledR}$ Coronary Stent System (Boston Scientific Corporation, Natick, MA). Although, there are three paclitaxel drug-release formulations (fast, moderate, and slow), only the moderate- and slow-release formulations have been tested in clinical trials. The moderate-release form of Taxus stent allows for an initial bolus release over the first 48 hours after stenting followed by a low-level release over the next 10 days. In these 10 days the slow-release formulation of Taxus stent has a drug release concentration of 8-10 times lower than that of the moderate-release formulation. ${ }^{24}$ Only the slow-release formulation is marketed for clinical use.

By making small changes in formulation, such as increasing drug dose, coating thickness, or drug-to polymer ratio,

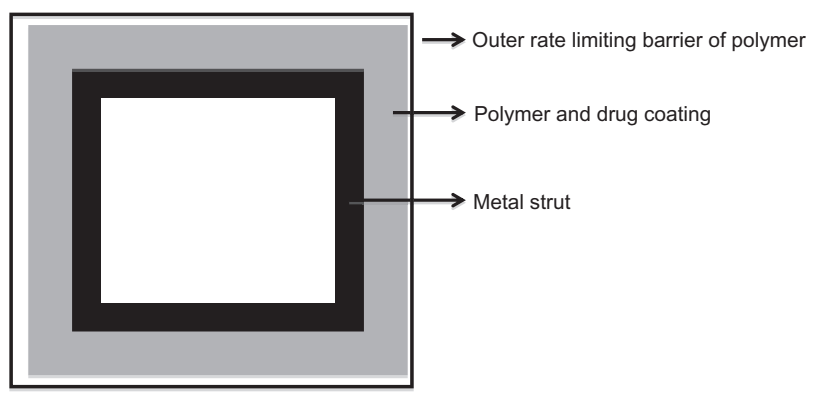

Figure 3 A cross-section through a stent strut. ${ }^{117}$ the release kinetics can be varied over a period of time..$^{25}$ A few characteristics of Food and Drug Administrationapproved stents are listed in Table 1. Parameters used in assessing a DES include stent size, total amount of drug loaded, dose of drug per unit area, duration of release, residual drug within stent, and thickness of coating material. ${ }^{26}$ The goal being to optimize drug release in order to achieve desired efficacy and minimize local vascular toxicity.

\section{Efficacy of stents \\ First generation DES}

The first in-man placement of a sirolimus-eluting stent (SES) occurred in 1999 as a part of a study of 30 patients with angina. ${ }^{27}$ At 8-month follow-up, there was no evidence of restenosis with minimal neointimal proliferation detected by intravascular ultrasound and quantitative coronary angiography. ${ }^{27}$ To compare the outcomes of the newly developed Cypher SES to conventional BMS, the Initial Double-Blind DES versus BMS Study (RAVEL) study was performed. ${ }^{28}$ RAVEL randomized 238 patients with low-risk lesions to receive BMS or SES. At 1-year follow-up; SES had a restenosis rate of $0 \%$ while BMS had a restenosis rate of $27 \% .^{28}$ A subsequent larger study, Study of SirolimusCoated Bx Velocity Balloon-Expandable Stent in Treatment of de Novo Native Coronary Lesions (SIRIUS), enrolled 1058 patients with more complex lesions and showed that target lesion revascularization (TLR) occurred in $4.9 \%$ of the SES patients vs $20 \%$ in the BMS patients at 12 months $(P<0.001) .{ }^{29}$ This significant difference persisted through 5 years of follow-up (Figure 4). ${ }^{30}$ Single center and multicenter registries, the Rapamycin-Eluting Stent Evaluated at Rotterdam Cardiology Hospital registry and the Arterial Revascularization Therapies Study registry also illustrated similar benefits for SES in the "real world setting." 31,32 Other subsets including diabetics, ST segment elevation myocardial infarctions, chronic total occlusions, saphenous vein grafts showed significantly better outcomes for in-stent restenosis, TLR, and major adverse cardiovascular events for SES. ${ }^{33-46}$

Primary Stenting of Totally Occluded Native Coronary Arteries II (PRISON II) study enrolled 200 patients with chronic total occlusions and randomized 100 to SES and 100 to BMS and found significantly better outcomes in the SES arm (Table 2). The GruppoItaliano di Studio sullo Stent nelle Occlisioni Coronariche (GISSOC) trial looked at 152 chronic total occlusions with 78 receiving SES and 74 receiving BMS; it showed SES to have significantly greater minimal 
Table I Specifications of the Food and Drug Administration-approved drug-eluting stents

\begin{tabular}{|c|c|c|c|c|c|c|}
\hline Stent & Drug $(\mu \mathrm{m})$ & Polymer & $\begin{array}{l}\text { Polymer } \\
\text { thickness }(\mu \mathrm{m})\end{array}$ & $\begin{array}{l}\text { Release } \\
\text { kinetics } \\
28 \text { days }\end{array}$ & Metal & $\begin{array}{l}\text { Strut } \\
\text { thickness }(\mu \mathrm{m})\end{array}$ \\
\hline $\begin{array}{l}\text { Cypher }^{\circledR} \text { Stent } \\
\text { (Cordis Corporation, } \\
\text { Minneapolis, MN) }\end{array}$ & Sirolimus (140) & $\begin{array}{l}\text { Polyethylene co-vinyl acetate } \\
\text { and poly-n-butyl methacrylate }\end{array}$ & 12.6 & $80 \%$ & SS & 140 \\
\hline $\begin{array}{l}\text { Taxus }^{\circledR} \\
\text { Express }^{2 \circledast} \\
\text { Coronary Stent System } \\
\text { (Boston Scientific } \\
\text { Corporation, Natick, MA) }\end{array}$ & Paclitaxel (100) & $\begin{array}{l}\text { Poly (styrene-b-isobutylene- } \\
\text { b-styrene) }\end{array}$ & 16.0 & $<10 \%$ & SS & 132 \\
\hline $\begin{array}{l}\text { Taxus } \\
\text { Liberté }^{\circledR} \\
\text { Paclitaxel-Eluting } \\
\text { Coronary Stent System } \\
\text { (Boston Scientific Corporation) }\end{array}$ & Paclitaxel (I00) & $\begin{array}{l}\text { Poly (styrene-b-isobutylene- } \\
\text { b-styrene) }\end{array}$ & 16.0 & $<10 \%$ & SS & 97 \\
\hline $\begin{array}{l}\text { Endeavor }^{\circledR} \\
\text { Sprint Zotarolimus-Eluting } \\
\text { Coronary Stent System } \\
\text { (Medtronic, Inc) }\end{array}$ & Zotarolimus (100) & Phosphorylcholine & 4.1 & $95 \%$ & $\mathrm{CoCr}$ & 91 \\
\hline $\begin{array}{l}\text { Xience } \mathrm{V}^{\circledR} \\
\text { Everolimus Eluting } \\
\text { Coronary Stent (Abbott } \\
\text { Laboratories, Abbott Park, IL) }\end{array}$ & Everolimus (100) & $\begin{array}{l}\text { Polyvinylidene fluoride } \\
\text { co-hexafluoropropylene and } \\
\text { poly-n-butly methacrylate }\end{array}$ & 7.6 & $80 \%$ & $\mathrm{CoCr}$ & 81 \\
\hline
\end{tabular}

Note: Reprinted from J Am Coll Cardiol, Vol. 56, Garg and Serruys, Coronary stents: current status, Pp. SI-S42, Copyright (20I0), with permission from Elsevier. Abbreviations: SS, stainless steel; CoCr, cobalt chromium.

luminal diameter at 8-month follow-up (1.98 $\pm 0.57 \mathrm{~mm}$ vs $0.98 \pm 0.80 \mathrm{~mm}, P<0.001) .{ }^{47}$ One small nonrandomized study of 38 patients with SES vs 37 patients with BMS in saphenous vein graft lesions demonstrated less in-stent late loss $(0.38 \mathrm{~mm}$ vs $0.79 \mathrm{~mm}, P<0.05)$, binary in-stent restenosis $(11.3 \%$ vs $30.5 \%, P<0.05)$, and TLR $(5.3 \%$ vs $21.6 \%, P<0.05)$ in the SES group at 6 months. However, at long-term follow-up of this small cohort, there was increased mortality in the SES arm $(29 \%$ vs $0 \%, P<0.001)$ with loss of benefit of SES in TLR ( $34 \%$ vs $38 \%, P=0.15) .{ }^{48,49}$ But a more recent meta-analysis of DES compared to BMS in 7994 confirmed the benefits of DES and did not find any increased mortality or morbidity related to DES in saphenous vein grafts. ${ }^{50}$ In the just reported Is DESing Associated With

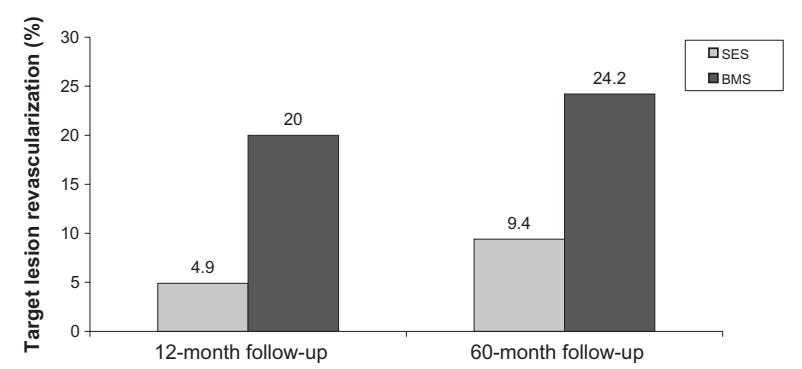

Figure 4 Results of the Sirolimus-Eluting Stent in De Novo Native Coronary Lesions (SIRIUS) trial showing sirolimus-eluting stent (SES) vs base metal stent (BMS) at 12-month and 60-month follow-up..$^{30,118}$
Improved Results in Coronary Artery Bypass Grafts (ISAR CABG) trial, 610 patients from four centers received either a DES or BMS in their saphenous vein grafts and showed that there were significant reductions of TLR in the DES group (7.2\% vs $12.9 \%, P=0.020) .^{51}$

The Taxus paclitaxel-eluting stent (PES) was developed at the same time SES was being tested. The Taxus PES showed significant improvements in minimal luminal diameter (2.60 $\pm 0.49 \mathrm{~mm}$ vs $2.19 \pm 0.65 \mathrm{~mm}, P<0.01)$, diameter stenosis ( $13.56 \pm 11.77 \mathrm{~mm}$ vs $27.23 \pm 16.69 \mathrm{~mm}, P<0.01)$, and late lumen loss $(0.36 \pm 0.48 \mathrm{~mm}$ vs $0.71 \pm 0.48 \mathrm{~mm}$, $P<0.01)$ when compared to BMS in de novo coronary lesions with 6- and 12-month follow-up. ${ }^{52}$ Larger randomized trials including patients with ST segment elevation myocardial infarctions and more complex lesions also confirmed the benefits of PES over BMS. ${ }^{39,40,52-61}$ In the Taxus Stent Evaluated at Rotterdam Cardiology Hospital report of 2-year

Table 2 Results of PRImary Stenting of totally Occluded Native coronary arteries II (PRISON II) trial'I9

\begin{tabular}{llll}
\hline & SES & BMS & $P$ value \\
\hline Binary in-stent restenosis & $7 \%$ & $36 \%$ & $P<0.00$ I \\
In-segment restenosis & $11 \%$ & $41 \%$ & $P<0.000$ I \\
Target lesion revascularization & $4 \%$ & $19 \%$ & $P<0.00$ I \\
\hline
\end{tabular}

Abbreviations: BMS, bare metal stent; SES, sirolimus-eluting stent. 
follow-up, it was reported that PES had similar efficacy to SES for restenosis. ${ }^{62}$

Several studies have compared the outcomes of unselected patients with SES vs PES. ${ }^{63,64}$ The Sirolimus-Eluting Versus PES for Coronary Revascularization study (SIRTAX) looked at 1012 patients with 503 receiving SES and 509 receiving PES. Initial follow-up at 8 months showed superiority of SES with significantly lower rates of in-stent late loss and binary in-stent restenosis with seemingly fewer TLR and major adverse cardiovascular events. However, after 5 years of follow-up, there were no significant differences in any of the measured outcomes.

A meta-analysis of 16 randomized trials with over 8000 patients comparing SES and PES showed that patients who had SES had lower TLR (hazard ratio [HR]: 0.74, 95\% confidence interval [CI]: $0.63-1.03, P<0.001)$ and significantly less incidence of stent thrombosis (HR: 0.66, 95\% CI: 0.46-0.94, $P=0.02) .{ }^{65}$ However, there were no significant differences for the risk of death (HR: $0.92,95 \% \mathrm{CI}: 0.74-1.13, P=0.43$ ) or myocardial infarction (HR: 0.84, 95\%CI: 0.69-1.03, $P=0.10)$. A more recent, but smaller meta-analysis of 810 patients showed similar outcomes with significantly less TLR (HR: $0.61,95 \% \mathrm{CI}: 0.44-0.85, P=0.004$ ) in patients who received SES when compared to PES. ${ }^{66}$

Two studies compared SES vs PES in diabetics: DES in Patients with DIABETES Mellitus (DES-DIABETES) trial and the Intracoronary Stenting and Angiographic Results: Do Diabetic Patients Derive Similar Benefits from PaclitaxelEluting and SES (ISAR-DIABETES) trial. DES-DIABETES showed significantly less in-stent late loss $(0.13 \mathrm{~mm}$ vs $0.53 \mathrm{~mm}, P<0.001)$ and a lower rate of binary in-stent restenosis $(3.4 \%$ vs $18.2 \%, P<0.001)$ in patients who received SES. ${ }^{67-69}$ ISAR-DIABETES also showed significantly better outcomes with less in-stent late loss $(0.19 \mathrm{~mm}$ vs $0.46 \mathrm{~mm}$, $P<0.001)$ and binary in-stent restenosis (4.9\% vs $13.6 \%$, $P<0.001)$ in patients who received SES when compared to patients who received PES. No significant differences were seen in death or myocardial infarction but there was significantly less TLR in SES patients $(3.5 \%$ vs $11.0 \%$ at 24 months) in the DES-DIABETES study. ${ }^{68}$ In the ST segment elevation myocardial infarctions population, SES had lower in-stent restenosis $(5.9 \%$ vs $14.8 \%, P=0.03)$ and instent late lumen loss $(0.09 \pm 0.45 \mathrm{~mm}$ vs $0.33 \pm 0.68 \mathrm{~mm}$, $P=0.002$ ) than PES. ${ }^{70}$ Like other SES vs PES studies, there were no significant differences in major adverse cardiovascular events between the two types of DES. At 3-year follow-up there continued to be no significant differences in major adverse cardiovascular events. ${ }^{71}$
For unprotected left main stenting, there were no significant differences between SES and PES for death, myocardial infarction, or TLR. There was no difference in angiographic restenosis at 1 year. ${ }^{72}$ In a study of 360 nondiabetic patients with small vessels, SES had significantly less in-stent late loss with a difference of $0.32 \mathrm{~mm}(P<0.001)$ when compared to PES and binary in-stent restenosis (relative risk [RR]: 1.67, 95\% CI: $1.00-2.79, P=0.047$ ) as well as less TLR (RR: 2.24, 95\% CI: $1.20-4.17, P=0.008)$ when compared to PES. ${ }^{73}$ While many smaller studies with unselected patients with diabetes, left main coronary artery disease, and acute infarctions show SES superiority over PES at short-term follow-up, at 5 years the SIRTAX trial demonstrated no difference in outcomes between SES vs PES. ${ }^{63,64,67-70,72,73}$

\section{Second generation DES}

While first generation coronary stents utilized stainless steel for their metal backbone, second generation coronary stents are made with cobalt chromium struts. Cobalt chromium has an advantage over its predecessor, stainless steel, in that it is more radiopaque, it has more radial force, and it is thinner.

The first of the two approved second generation DES is the Endeavor stent which utilizes a phosphorylcholine polymer to deliver a sirolimus analog, zotarolimus. Imaging studies with angioscopy and optical coherence tomography have demonstrated the zotarolimus-eluting stent (ZES) have better neointimal coverage than SES (comparable to BMS). ${ }^{74,75}$ The Medtronic Endeavor Drug Eluting Coronary Stent System in Coronary Artery Lesions (Endeavor II) trial, the first randomized controlled trial comparing ZES to BMS, showed that ZES had significantly lower in-stent late loss, binary restenosis, and TLR in 1197 patients at 9-month follow-up (Figure 5). ${ }^{76}$ At 5-year follow-up, ZES continued to have significantly lower major adverse cardiovascular events, target vessel revascularization, and TLR. ${ }^{77}$ Stent thrombosis was low at $0.2 \%$ with ZES and $0.3 \%$ with BMS. ${ }^{77}$

Comparing ZES to SES demonstrated ZES had more in-stent late loss $(0.34 \pm 0.44 \mathrm{~mm}$ vs $0.13 \pm 0.32 \mathrm{~mm}$, $P<0.001)$, binary in-stent restenosis $(11.7 \%$ vs $4.3 \%$, $P=0.04)$, and TLR $(9.8 \%$ vs $3.5 \%, P=0.04)$ at 9 months. $^{78}$ However, after 5 years ZES vs SES patients had lower allcause mortality $(5.2 \%$ vs $13.0 \%, P=0.02)$, myocardial infarction $(1.0 \%$ vs $4.6 \%, P=0.03)$, and major adverse cardiovascular events $(14.0 \%$ vs $22.2 \%, P=0.05)$ compared to patients who received SES. ${ }^{79}$ There was no difference between ZES and SES for target vessel revascularization or stent thrombosis at 5 years. ${ }^{79}$ The Endeavor IV trial compared ZES to PES and showed no significant differences in target 
A

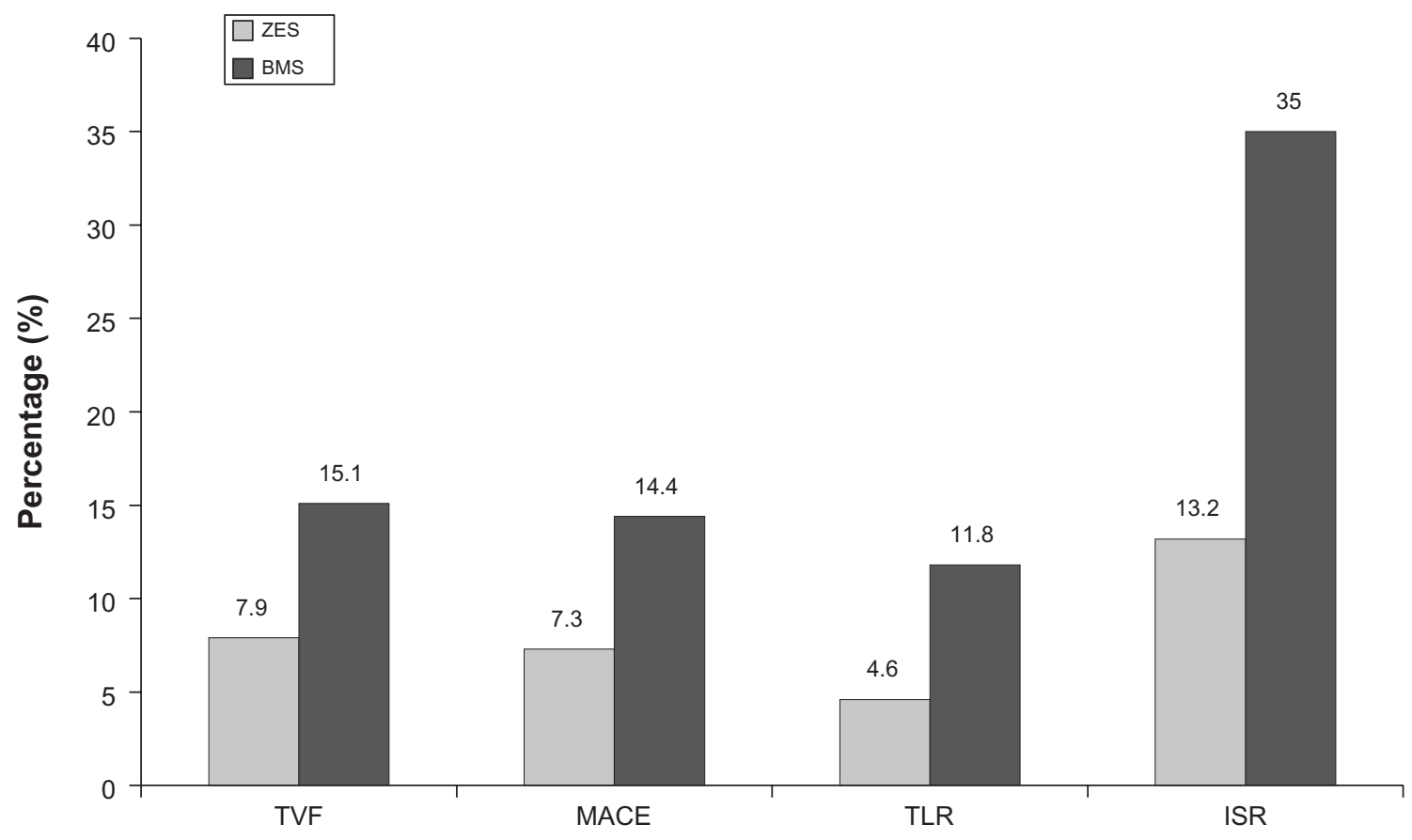

B

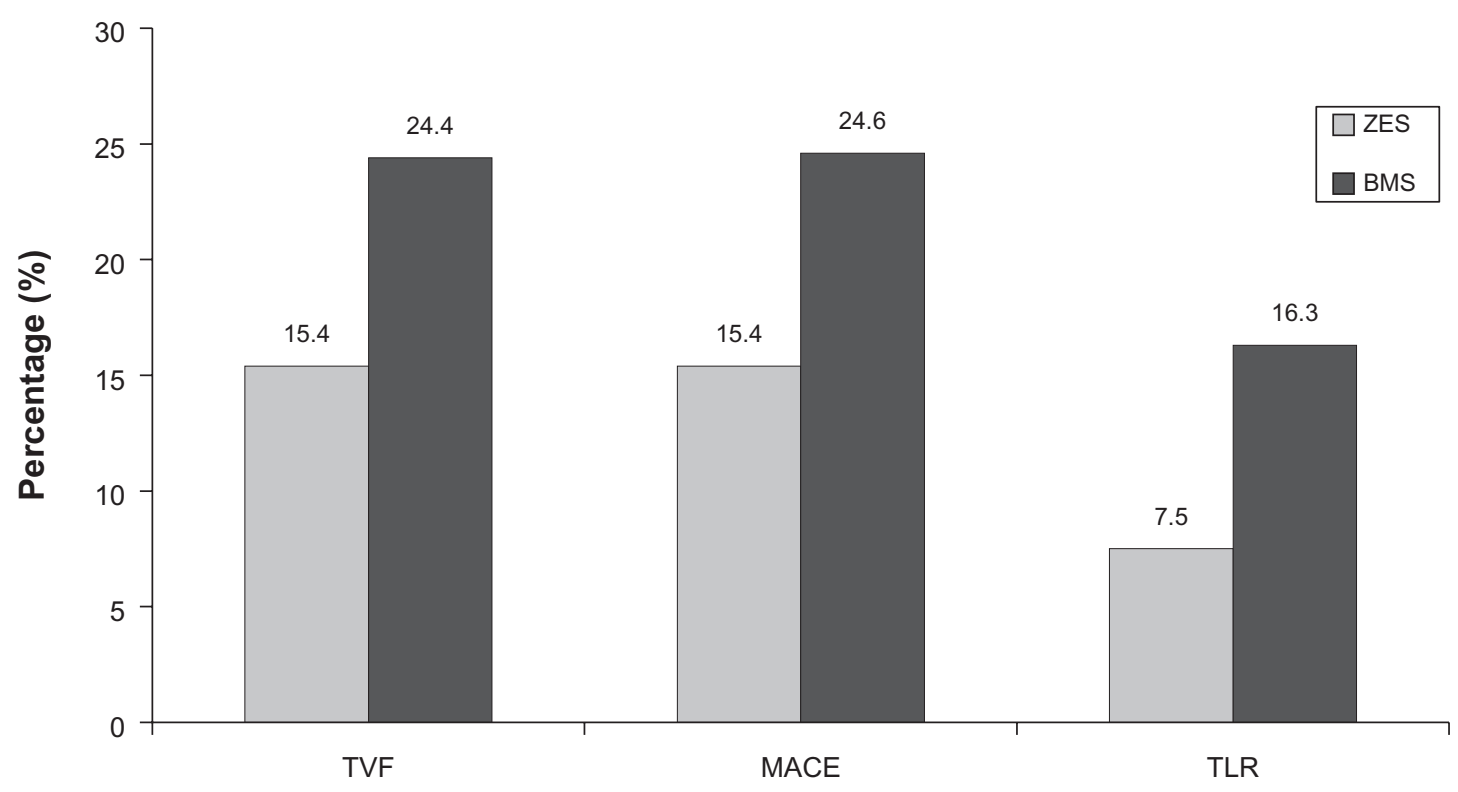

Figure 5 Results of the Endeavor II Clinical Trial: The Medtronic Endeavor Drug Eluting Coronary Stent System in Coronary Artery Lesions showing zotarolimus-eluting stent (ZES) versus bare metal stent (BMS) at (A) 9-month follow-up and (B) 60-month follow-up. ${ }^{76,77}$

Abbreviations: ISR, in-stent restenosis; MACE, major adverse cardiovascular events; TLR, target lesion revascularization; TVF, target vessel failure.

vessel revascularization, cardiac death, myocardial infarction, or stent thrombosis at 12 months. ${ }^{80}$

The other approved second generation DES is the Xience $\mathrm{V}^{\circledR}$ Everolimus Eluting Coronary Stent (Abbott Laboratories, Abbott Park, IL), an everolimus-eluting stent (EES) with a biocompatible polymer and a synthetic derivative of sirolimus, everolimus. The first randomized control trial looking at the safety and efficacy of EES, Clinical Evaluation of the Xience V Everolimus Eluting Coronary Stent Systems (SPIRIT) I, was conducted in 60 patients with 28 receiving EES and 32 receiving a BMS in native coronary lesions which showed significantly lower in-stent 
late loss $(0.10 \mathrm{~mm}$ vs $0.87 \mathrm{~mm}, P<0.001)$ and binary in-stent restenosis $(0 \%$ vs $25.9 \%, P=0.01)$ in the EES patients, suggesting effective suppression of neointimal growth at 6 months. ${ }^{81}$ In SPIRIT II, which compared 223 patients who received EES with 77 patients who received PES, there was significantly less in-stent late loss in the EES patients when compared to the PES patients $(0.11 \pm 0.27 \mathrm{~mm}$ vs $0.36 \pm 0.39 \mathrm{~mm}, P<0.0001)$ at 6 months, but no significant differences in death, myocardial infarction, and TLR. ${ }^{82}$ This same cohort of patients showed a nonsignificant trend towards benefit of EES when compared to PES in respect to death, myocardial infarction, and TLR at 4 years. ${ }^{82}$

The SPIRIT III trial enrolled over 1000 patients and also showed that in-stent late lumen loss was significantly less in the patients who received EES when compared to patients who received PES ( $0.14 \mathrm{~mm}$ vs $0.28 \mathrm{~mm}, P \leq 0.004)$ as well as having fewer major adverse cardiac events at 9 months $(6.0 \%$ vs $10,3 \%, P=0.02) .{ }^{83}$ Subsequent studies have shown an advantage for EES compared to PES in a large population of patients (SPIRIT IV and the Second Generation EverolimusEluting and PES in Real-Life Practice [COMPARE] study) with significantly lower rates of myocardial infarction, TLR, as well as stent thrombosis. ${ }^{84,85}$ There has been criticism that EES has yet to be compared to SES which is regarded as the most efficacious first generation DES. This should be addressed in the currently ongoing Efficacy of Xience/ Promus versus Cypher in Reducing Late Loss After Stenting (EXCELLENT) trial. $^{86}$

Newer coronary stents include those that have a novel polymer coating, are biodegradable, or are completely polymer free. The Endeavor ${ }^{\circledR}$ Resolute Zotarolimus Eluting Coronary Stent (Medtronic, Inc) is the next version of the Endeavor ZES undergoing clinical evaluation. This ZES consists of the Driver cobalt chromium stent platform and a polymeric coating which is a blend of three different polymers allowing for a delayed drug release, such that at least $85 \%$ of the zotarolimus is released within 60 days, with the remainder being released within 180 days. The Endeavor Resolute stent has been compared to the Xience V stent in the Resolute All-Comers trial. ${ }^{87}$ This trial enrolled 2300 patients who were randomized in a 1:1 ratio to treatment with either the Resolute ZES or the Xience V EES. At 12-month follow-up the Resolute ZES was noninferior to EES with respect to the primary clinical end point of target lesion failure, a composite of cardiac death, target vessel myocardial infarction, and clinically indicated TLR (ZES $8.2 \%$ vs EES $8.3 \%$, noninferiority $P<0.001) .{ }^{87}$ This is the beginning of a wealth of new stent technology. Further results are awaited.

\section{Safety of DES}

DES constitutes the vast majority of stents used to treat coronary lesions due to their low rates of restenosis when compared to BMS. ${ }^{88}$ In 2006, safety concerns were raised regarding the risk of stent thrombosis with DES. ${ }^{89} \mathrm{~A}$ metaanalysis published in 2006 comparing first generation DES with BMS concluded that there was increased noncardiac mortality at $2-3$ years following stent placement. ${ }^{89}$ The cause of the increased noncardiac mortality was not clear, nor was there any relationship with stent thrombosis. ${ }^{89}$ Subsequently, the Basel Stent Cost-effectiveness Trial - Late Thrombotic Events (BASKET-LATE) trial prospectively randomized 746 patients undergoing PCI to DES or BMS to determine the rate of late cardiac events after discontinuation of dual antiplatelet therapy. The study demonstrated a 3.6\% increased risk of cardiac death $(P<0.01)$ and a $3.8 \%$ increased risk of nonfatal myocardial infarction $(P<0.04) 7-18$ months in the DES group. There was no significant difference in rates of angiographically-confirmed stent thrombosis; however, any late death or myocardial infarction was assumed to represent a "thrombosis-related event." "To Two major studies published in 2007, the combined analysis of the Cypher SES trials (RAVEL, SIRIUS, European SIRIUS, and Canadian SIRIUS $)^{91}$ and the Swedish Coronary Angiography and Angioplasty Registry showed an increased risk of death or Q wave myocardial infarction with DES compared to BMS, which seemed to corroborate these findings. ${ }^{92}$

These early studies questioning DES safety prompted two important steps: (1) a better definition of stent thrombosis was applied in a standardized fashion across all clinical trials and (2) larger meta-analyses were performed that were powered to detect differences in stent thrombosis rates. In 2007, the Academic Research Consortium defined stent thrombosis as definite, probable, or possible (Table 3). ${ }^{93}$ Most experts believe that the Academic Research Consortium definitions of "definite and probable" stent thrombosis are the most precise methodology to estimate the occurrence of this event.

Using these new Academic Research Consortium criteria, four large meta-analyses found no difference in the rates of death, myocardial infarction, or stent thrombosis between DES and BMS (Figure 6). ${ }^{94-97}$ The largest of these studies examined 8646 patients undergoing DES and BMS implantation followed for 4 years and saw no difference in death or myocardial infarction. ${ }^{94}$ This reassuring data was followed by a pooled analysis of four randomized controlled trials 
Table 3 Academic Research Consortium definitions of stent thrombosis ${ }^{116}$

\begin{tabular}{ll}
\hline Category & Definition \\
\hline Definite ST & - Angiographic or pathologic confirmation of partial \\
& or total thrombotic occlusion within the peristent \\
& region AND at least ONE of the following, \\
& additional criteria: \\
& - Acute ischemic symptoms \\
& - Ischemic electrocardiogram changes \\
& - Elevated cardiac biomarkers \\
Probable ST & - Any unexplained death within 30 days of stent \\
& implantation \\
& - Any myocardial infarction, which is related to \\
& documented acute ischemia in the territory of the \\
& implanted stent without angiographic confirmation \\
& of stent thrombosis and in the absence of any \\
Possible ST & other obvious cause
\end{tabular}

Abbreviation: ST, stent thrombosis.

with 1748 patients undergoing PCI with DES or BMS. The DES group had a mortality of $6.7 \%$ compared to $5.3 \%$ in the BMS group this was not statistically significant. ${ }^{95}$ Finally, two meta-analyses performed similar comparisons, which actually found the overall event rate to be significantly lower in the DES group. There were no increased rates of death or probable/definite stent thrombosis. ${ }^{96,97}$ These studies demonstrated that appropriate dual antiplatelet therapy for 1 year was necessary to preclude the risk of stent thrombosis and ensure the safety of DES.

Second generation DES theoretically have a lower risk of stent thrombosis due to earlier intimal coverage (Table 4). ${ }^{74,98}$ Angioscopy studies with ZES have shown neointimal stent coverage similar to BMS at 3-month follow-up. ${ }^{74}$ Because the rate of stent thrombosis is very low, no study comparing ZES to BMS has been powered to detect differences in stent thrombosis. ${ }^{99}$ There is evidence of noninferiority for ZES when compared to first generation DES. The Danish Organization for Randomized Trials with Clinical Outcome (SORT-OUT) trial and Comparison of the Efficacy and Safety of ZES with Sirolimus-Eluting and PES for Coronary Lesions (ZEST) trials comparing ZES to first generation DES, showed no difference in the rate of stent thrombosis. ${ }^{100}$ The ongoing Patient Related Outcomes with Endeavor versus Cypher Stenting Trial (PROTECT) will enroll 8800 patients and will report a primary endpoint of definite/probable stent thrombosis at 3-year follow-up. This will be the first larger scale data regarding the long-term safety of ZES. ${ }^{101}$

EES have consistently shown lower rates of probable/ definite stent thrombosis compared to first generation DES in a series of clinical trials. Two trials, SPIRIT IV and COMPARE, showed statistically significant lower rates of stent thrombosis with everolimus stents when compared to PES. The ongoing EXCELLENT trial will be the first trial to compare the safety and efficacy of EES to SES. ${ }^{86}$

\section{Quality of life, patient satisfaction, and acceptability}

Clinical trials in stable patients with coronary artery disease have failed to show a reduction in mortality or recurrent myocardial infarction with PCI. ${ }^{102}$ The primary benefit of PCI is relief of angina. ${ }^{103,104}$ Patient quality of life and outcomes are significantly improved by a reduction in their angina frequency and severity. ${ }^{105}$ Recently the utilization of PCI in patients with stable coronary disease has come into question. A substudy of the Clinical Outcomes Utilizing Revascularization and Aggressive Drug Evaluation (COURAGE) trial published in 2007 compared the use of
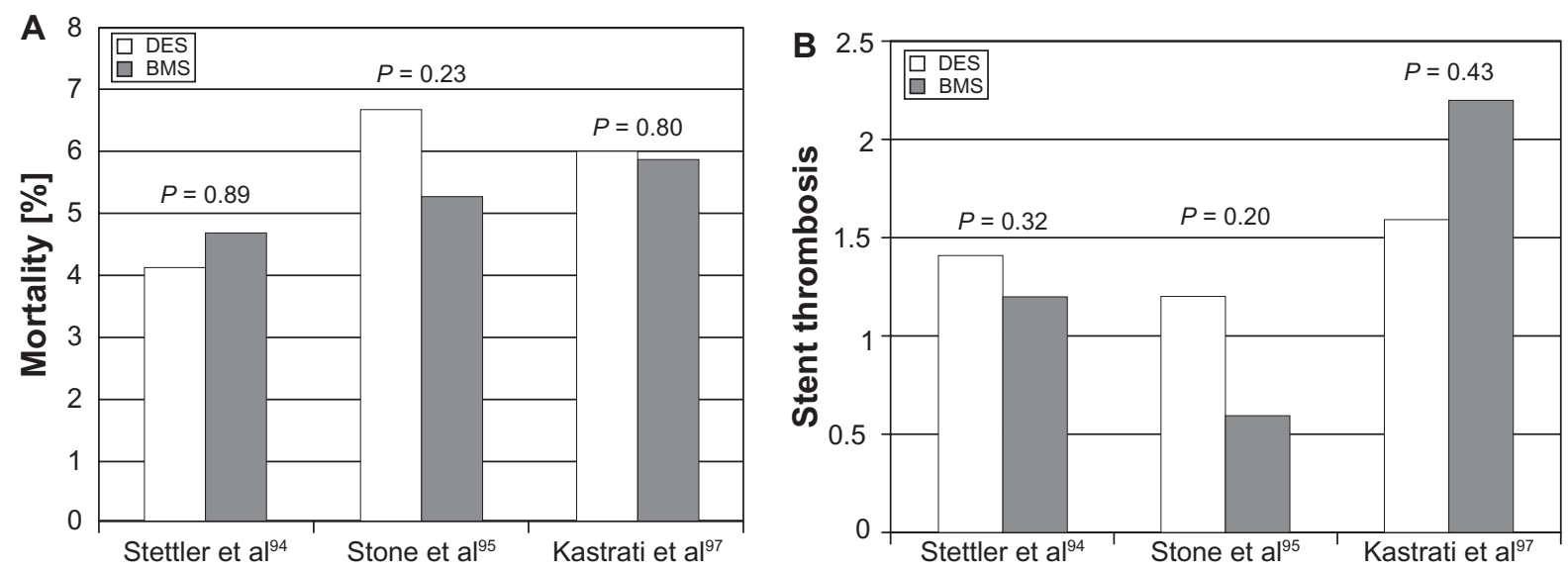

Figure 6 (A) Relative rates of stent thrombosis in drug-eluting stent (DES) and bare metal stent (BMS) from three large meta-analyses. (B) Overall mortality in DES and BMS. $94,95,97$ 
Table 4 First and second generation drug-eluting stents (DES)

\begin{tabular}{lc}
\hline First generation DES & Second generation DES \\
\hline $\begin{array}{l}\text { Sirolimus-eluting stents } \\
\text { Cypher }{ }^{\circledR} \text { Stent (Medtronic, } \\
\text { Inc, Minneapolis, MN) }\end{array}$ & $\begin{array}{c}\text { Zotarolimus-eluting stents } \\
\text { Endeavor }^{\circledR}\end{array}$ \\
Paclitaxel-eluting stents $_{\text {Taxus }^{\circledR}}$ & Everolimus-eluting stents \\
& Xience V $^{\circledR}$ Everolimus Eluting \\
& Coronary Stent (Abbott \\
& Laboratories, Abbott Park, IL) \\
& Promus ${ }^{\circledR}$ Everolimus-Eluting \\
& Coronary Stent System (Boston \\
& Scientific Corporation, Natick, MA) \\
&
\end{tabular}

optimal medical therapy to PCI and found that PCI led to improvements in angina frequency, quality of life, and patient satisfaction but that these differences disappeared at 3-year follow-up. ${ }^{106}$ It is important to understand that the COURAGE trial suffered from serious limitations including the requirement that therapy was directed by angiography, the patient population was highly selected, there was very low rate of DES utilization, and a high crossover rate from medical therapy to PCI was permitted which weakens conclusions regarding late outcomes. A number of trials have demonstrated significant improvement in angina and quality of life with PCI in certain subgroups including the elderly, ${ }^{107}$ those with severe angina, ${ }^{108}$ and diabetics. ${ }^{105}$ An integrated approach to the management of angina including revascularization, medical therapy, and cardiac rehabilitation can improve quality of life and patient focused outcomes.

The symptom of angina pectoris results in significant impairment of several health-related quality of life measures. Exercise performance and overall physical activity declines dramatically with exertional angina. Psychologically, patients with angina have a higher risk of depression, poor disease related perception, and overall self-reported quality of life. ${ }^{109}$ Proper management of angina leads to improvement in emotional wellbeing, physical activity, and patient perception of general health. ${ }^{110}$

The challenge of the past several years has been to determine the role of PCI in the management of angina. Several landmark studies demonstrated improvement in anginal symptoms with PCI (Figure 7). The Angioplasty Compared to Medicine trial randomized 212 veterans with single vessel coronary artery disease and inducible ischemia on stress testing to medical management or PTCA. In this study at 6-month follow-up, $62 \%$ of patients in the PTCA group were angina free compared with $47 \%$ of patients in the medical group $(P<0.05) .{ }^{103}$ The Medicine, Angioplasty or Surgery Study trial randomized 214 patients with stable angina, isolated proximal left anterior descending coronary artery disease, and normal left ventricular function to

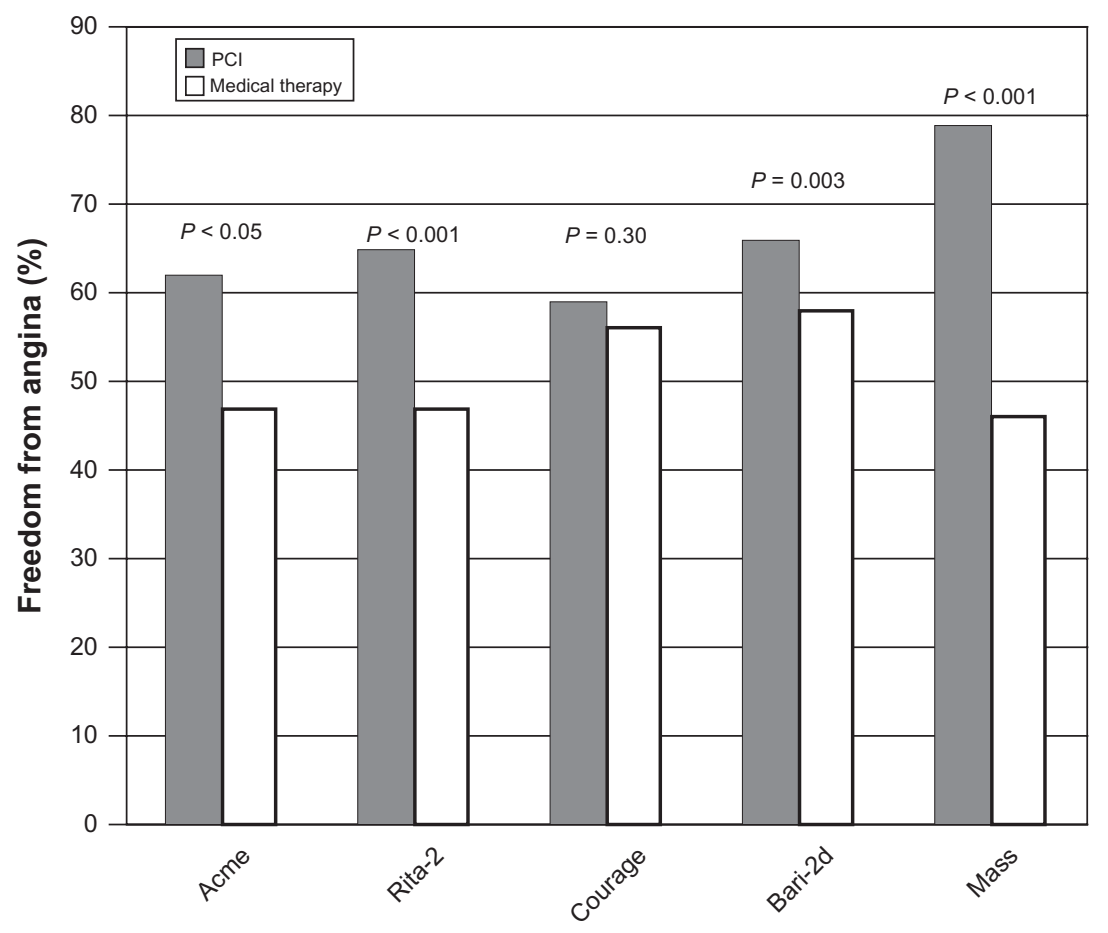

Figure 7 Freedom from angina in trials comparing medical therapy to percutaneous coronary intervention (PCl).

Abbreviations: ACME, Angioplasty Compared to Medicine trial; RITA-2, Second Randomized Intervention Treatment of Angina trial; COURAGE, Clinical Outcomes Utilizing Revascularization and Aggressive Drug Evaluation trial; BARI-2D, Bypass Angioplasty Revascularization Investigation 2 Diabetes trial; MASS, Medicine, Angioplasty, or Surgery Study. 
coronary artery bypass graft, PTCA, or medical therapy. Both revascularization groups, coronary artery bypass graft and PTCA, showed improvements in angina. The PTCA group was superior to medical therapy for control of angina at 3-year follow-up. ${ }^{111}$ Finally, the Second Randomized Intervention Treatment of Angina (RITA-2) trial randomized 1018 patients with single or multivessel coronary artery disease to PTCA or medical therapy. At 6-month follow-up, the PTCA group showed improvements in Canadian Cardiovascular Society angina class and exercise performance when compared to the medical therapy arm. ${ }^{104}$ Outcomes analysis showed improvement in quality of life factors including overall vitality and tolerance of physical activity in the PTCA group that lasted 1 year. At 3-year follow-up, the difference between the two groups became negligible, but in the interim, there was $27 \%$ crossover from the medical therapy to the PTCA arm. ${ }^{112}$

The COURAGE trial included several quality of life endpoints. ${ }^{106}$ The investigators assessed angina related specific health status with the Seattle Angina Questionnaire and overall physical and mental function with the RAND-36 health survey. ${ }^{106}$ The PCI group showed significant improvement in freedom from angina up to 2-year follow-up. The vast majority of stents were BMS, and the rates of restenosis were not published. In the five domains assessed by the RAND-36 survey (physical functioning, physical limitation, vitality, pain, and general health), there were significant benefits in the PCI group at 6-month follow-up, but again these benefits were lost at 2-year follow-up. ${ }^{106}$

The time-limited benefits with PCI are likely due to a significant number of medical therapy patients crossing over to PCI. COURAGE had a highly selected patient population. Patients were enrolled only after coronary angiography was performed. COURAGE excluded over $90 \%$ patients screened for unclear reasons. The data defining the reasons for exclusion has not been published. The observed annual rate of cardiac mortality in COURAGE was approximately $0.4 \%$, which represents an extremely low risk cohort and suggests that high-risk patients were excluded. COURAGE enrolled $70 \%$ of patients with two- or three-vessel disease. ${ }^{113}$ Yet only $36 \%$ of patients received more than one stent. This suggests that revascularization was incomplete in a significant proportion of the PCI arm. Moreover, $42 \%$ of patients in the study had no or minimal angina (Canadian Cardiovascular Society class 0 or 1 ), as such it would be difficult to detect differences in anginal severity or frequency. ${ }^{113}$ A significant proportion of the medical therapy arm crossed over to PCI which may account for the loss of difference between the two groups at long-term follow-up. Of the symptomatic group in the medical therapy arm, 32\% were subsequently revascularized for severe or worsening symptoms. Finally, only $2.7 \%$ of patients in COURAGE received a DES and the late loss of anginal benefit may be due in part to BMS in-stent restenosis. ${ }^{113}$

The Trial of Invasive Versus Medical Therapy in Elderly Patients (TIME) examined the use of PCI in the elderly. TIME randomized 301 patients over the age of 75 with stable angina to invasive assessment with medical therapy or medical therapy alone. ${ }^{114}$ Patients randomized to the invasive strategy had a lower rate of major adverse cardiovascular events (death, myocardial infarction, or repeat hospitalization) when compared to medical therapy (49\% vs $19 \%$, $P<0.0001) .{ }^{114}$ Other similar studies have found benefits in quality of life measures for elderly patients undergoing PCI. The Alberta Provincial Project for Outcomes Assessment in Coronary Heart Disease (APPROACH) trial included two cohorts of about 1600 elderly patients. One cohort had patients undergoing PCI or coronary artery bypass graft, and the other cohort was treated with medical therapy. At 4-year follow-up, all measures of the Seattle Angina Questionnaire including angina frequency and severity were improved in the revascularization arm. ${ }^{115}$

The baseline severity of angina before PCI appears to predict improvement in angina after revascularization. In a multivariate analysis of 1020 patients undergoing PCI for nonacute myocardial infarction, the best predictors of improvement in angina was physical limitation prior to PCI and severity of angina as assessed by the Seattle Angina Questionnaire. ${ }^{102}$ In fact, the Seattle Angina Questionnaire predicted improvement in angina better than the number of vessels involved, ejection fraction, or age. Similarly, subsequent studies have demonstrated that patients with angina who report overall poor quality of life see the greatest benefit in angina and quality of life following PCI. ${ }^{102}$

Diabetics often present with atypical symptoms of angina. However, diabetics who do present with stable angina appear to have significant symptom relief with revascularization. The Bypass Angioplasty Revascularization Investigation 2 Diabetes (BARI 2D) trial randomized 2364 patients with diabetes, coronary artery disease, and inducible ischemia on stress testing to medical therapy or revascularization. ${ }^{105}$ Only 59\% of patients exhibited typical angina. The 796 patients randomized to PCI showed improvements in worsening angina, new angina, subsequent coronary revascularization, and total rates of freedom from angina at 3-year follow-up. ${ }^{105}$ 
The bulk of evidence supports a combined approach to the management of patients with angina. Coronary revascularization with stent placement should be complemented with exercise training and medical therapy. Certain patients such as the elderly, diabetics, and those with severe angina see clear benefits in quality of life and overall health after PCI for stable angina. Due to the limitations of COURAGE, it is still unclear what the role of PCI will be in other categories of patients. Further studies examining complete revascularization with DES in patients with stable angina will be needed to clarify this question.

\section{Summary}

It is clear from the data gathered among thousands of patients studied in clinical trials that the development of DES was a major step forward in the advancement of PCI. Multiple risk benefit analyses have demonstrated the cost-effective use of DES in patients with coronary artery disease. Concerns over the risk of subacute stent thrombosis rates with DES have been mitigated with prolonged use of dual antiplatelet therapy and with the newer generation of DES. Currently, patients who cannot be or who are unwilling to be compliant with prolonged dual antiplatelet therapy should receive BMS. The goals of the next generation of DES will be increased deliverability, will address difficult subsets of patients such as those with bifurcation disease, and will continue to have an improved safety profile with lower risks of stent thrombosis.

\section{Disclosure}

The authors report no conflicts of interest in this work.

\section{References}

1. Gruentzig AR, King SB 3rd, Schlumpf M, Siegenthaler W. Long-term follow-up after percutaneous transluminal coronary angioplasty. The early Zurich experience. N Engl J Med. 1987;316(18):1127-1132.

2. de Feyter PJ, de Jaegere PP, Serruys PW. Incidence, predictors, and management of acute coronary occlusion after coronary angioplasty. Am Heart J. 1994;127(3):643-651.

3. Serruys PW, Strauss BH, Beatt KJ, et al. Angiographic follow-up after placement of a self-expanding coronary-artery stent. $N$ Engl $J$ Med. 1991;324(1):13-17.

4. Boersma E, Akkerhuis KM, Theroux P, Califf RM, Topol EJ, Simoons ML. Platelet glycoprotein IIb/IIIa receptor inhibition in nonST-elevation acute coronary syndromes: early benefit during medical treatment only, with additional protection during percutaneous coronary intervention. Circulation. 1999;100(20):2045-2048.

5. Liu MW, Roubin GS, King SB 3rd. Restenosis after coronary angioplasty. Potential biologic determinants and role of intimal hyperplasia. Circulation. 1989;79(6):1374-1387.

6. Virmani R, Farb A. Pathology of in-stent restenosis. Curr Opin Lipidol. 1999;10(6):499-506.

7. Bertrand OF, Sipehia R, Mongrain R, et al. Biocompatibility aspects of new stent technology. J Am Coll Cardiol. 1998;32(3):562-571.
8. Kastrati A, Mehilli J, Dirschinger J, et al. Intracoronary stenting and angiographic results: strut thickness effect on restenosis outcome (ISAR-STEREO) trial. Circulation. 2001;103(23):2816-2821.

9. Kereiakes DJ, Cox DA, Hermiller JB, et al. Usefulness of a cobalt chromium coronary stent alloy. Am J Cardiol. 2003;92(4):463-466.

10. Tamai H, Igaki K, Kyo E, et al. Initial and 6-month results of biodegradable poly-l-lactic acid coronary stents in humans. Circulation. 2000;102(4):399-404.

11. Pinchuk L, Wilson GJ, Barry JJ, et al. Medical applications of poly(styrene-block-isobutylene-block-styrene) (“SIBS"). Biomaterials. 2008;29(4):448-460.

12. Pinchuk L. A review of the biostability and carcinogenicity of polyurethanes in medicine and the new generation of 'biostable' polyurethanes. J Biomater Sci Polym Ed. 1994;6(3):225-267.

13. Virmani R, Guagliumi G, Farb A, et al. Localized hypersensitivity and late coronary thrombosis secondary to a sirolimus-eluting stent: should we be cautious? Circulation. 2004;109(6):701-705.

14. Kim JW, Seo HS, Park JH, et al. A prospective, randomized, 6-month comparison of the coronary vasomotor response associated with a zotarolimus- versus a sirolimus-eluting stent: differential recovery of coronary endothelial dysfunction. $J$ Am Coll Cardiol. 2009;53(18): $1653-1659$.

15. Costa JR Jr, Abizaid A, Costa R, et al. 1-year results of the hydroxyapatite polymer-free sirolimus-eluting stent for the treatment of single de novo coronary lesions: the VESTASYNC I trial. JACC Cardiovasc Interv. 2009;2(5):422-427.

16. Sousa JE, Sousa AG, Costa MA, Abizaid AC, Feres F. Use of rapamycinimpregnated stents in coronary arteries. Transplant Proc. 2003;35(3 Suppl):165S-170S.

17. Schiff PB, Fant J, Horwitz SB. Promotion of microtubule assembly in vitro by taxol. Nature. 1979;277(5698):665-667.

18. Marx SO, Marks AR. Bench to bedside: the development of rapamycin and its application to stent restenosis. Circulation. 2001;104(8): $852-855$.

19. Kim JS, Jang IK, Kim JS, et al. Optical coherence tomography evaluation of zotarolimus-eluting stents at 9-month follow-up: comparison with sirolimus-eluting stents. Heart. 2009;95(23):1907-1912.

20. Verheye S, Agostoni P, Dubois CL, et al. 9-month clinical, angiographic, and intravascular ultrasound results of a prospective evaluation of the Axxess self-expanding biolimus A9-eluting stent in coronary bifurcation lesions: the DIVERGE (Drug-Eluting Stent Intervention for Treating Side Branches Effectively) study. J Am Coll Cardiol. 2009;53(12): 1031-1039.

21. Hwang CW, Wu D, Edelman ER. Physiological transport forces govern drug distribution for stent-based delivery. Circulation. 2001;104(5): 600-605.

22. Hwang $\mathrm{CW}$, Wu D, Edelman ER. Impact of transport and drug properties on the local pharmacology of drug-eluting stents. Int $J$ Cardiovasc Intervent. 2003;5(1):7-12.

23. Acharya G, Park K. Mechanisms of controlled drug release from drugeluting stents. Adv Drug Deliv Rev. 2006;58(3):387-401.

24. Ranade SV, Miller KM, Richard RE, Chan AK, Allen MJ, Helmus MN. Physical characterization of controlled release of paclitaxel from the TAXUS Express2 drug-eluting stent. J Biomed Mater Res A. 2004; 71(4):625-634.

25. Taylor AJ, Gorman PD, Kenwood B, Hudak C, Tashko G, Virmani R. A comparison of four stent designs on arterial injury, cellular proliferation, neointima formation, and arterial dimensions in an experimental porcine model. Catheter Cardiovasc Interv. 2001;53(3): $420-425$.

26. Schwartz RS, Edelman ER, Carter A, et al. Drug-eluting stents in preclinical studies: recommended evaluation from a consensus group. Circulation. 2002;106(14):1867-1873.

27. Sousa JE, Costa MA, Abizaid A, et al. Lack of neointimal proliferation after implantation of sirolimus-coated stents in human coronary arteries: a quantitative coronary angiography and three-dimensional intravascular ultrasound study. Circulation. 2001;103(2):192-195. 
28. Morice MC, Serruys PW, Sousa JE, et al. A randomized comparison of a sirolimus-eluting stent with a standard stent for coronary revascularization. $N$ Engl J Med. 2002;346(23):1773-1780.

29. Holmes DR Jr, Leon MB, Moses JW, et al. Analysis of 1-year clinical outcomes in the SIRIUS trial: a randomized trial of a sirolimus-eluting stent versus a standard stent in patients at high risk for coronary restenosis. Circulation. 2004;109(5):634-640.

30. Weisz G, Leon MB, Holmes DR Jr, et al. Five-year follow-up after sirolimus-eluting stent implantation results of the SIRIUS (SirolimusEluting Stent in De-Novo Native Coronary Lesions) Trial. J Am Coll Cardiol. 2009;53(17):1488-1497.

31. Lemos PA, Serruys PW, van Domburg RT, et al. Unrestricted utilization of sirolimus-eluting stents compared with conventional bare stent implantation in the "real world": the Rapamycin-Eluting Stent Evaluated At Rotterdam Cardiology Hospital (RESEARCH) registry. Circulation. 2004;109(2):190-195.

32. Serruys PW, Onuma Y, Garg S, et al. 5-year clinical outcomes of the ARTS II (Arterial Revascularization Therapies Study II) of the sirolimus-eluting stent in the treatment of patients with multivessel de novo coronary artery lesions. $J$ Am Coll Cardiol. 2010;55(11): 1093-1101.

33. Sabate M, Jimenez-Quevedo P, Angiolillo DJ, et al. Randomized comparison of sirolimus-eluting stent versus standard stent for percutaneous coronary revascularization in diabetic patients: the diabetes and sirolimus-eluting stent (DIABETES) trial. Circulation. 2005;112(14):2175-2183.

34. Maresta A, Varani E, Balducelli M, et al. Comparison of effectiveness and safety of sirolimus-eluting stents versus bare-metal stents in patients with diabetes mellitus (from the Italian Multicenter Randomized DESSERT Study). Am J Cardiol. 2008;101(11):1560-1566.

35. Baumgart D, Klauss V, Baer F, et al. One-year results of the SCORPIUS study: a German multicenter investigation on the effectiveness of sirolimus-eluting stents in diabetic patients. J Am Coll Cardiol. 2007; 50(17):1627-1634.

36. Diaz de la Llera LS, Ballesteros S, Nevado J, et al. Sirolimus-eluting stents compared with standard stents in the treatment of patients with primary angioplasty. Am Heart J. 2007;154(1):164. e1-e6.

37. van der Hoeven BL, Liem SS, Jukema JW, et al. Sirolimus-eluting stents versus bare-metal stents in patients with ST-segment elevation myocardial infarction: 9-month angiographic and intravascular ultrasound results and 12-month clinical outcome results from the MISSION! Intervention Study. J Am Coll Cardiol. 2008;51(6):618-626.

38. Atary JZ, van der Hoeven BL, Liem SS, et al. Three-year outcome of sirolimus-eluting versus bare-metal stents for the treatment of STsegment elevation myocardial infarction (from the MISSION! Intervention Study). Am J Cardiol. 2010;106(1):4-12.

39. Di Lorenzo E, De Luca G, Sauro R, et al. The PASEO (PaclitAxel or Sirolimus-Eluting Stent Versus Bare Metal Stent in Primary Angioplasty) Randomized Trial. JACC Cardiovasc Interv. 2009;2(6): 515-523.

40. Di Lorenzo E, Sauro R, Varricchio A, et al. Benefits of drug-eluting stents as compared to bare metal stent in ST-segment elevation myocardial infarction: four year results of the PaclitAxel or SirolimusEluting stent vs bare metal stent in primary angiOplasty (PASEO) randomized trial. Am Heart J. 2009;158(4):e43-e50.

41. Menichelli M, Parma A, Pucci E, et al. Randomized trial of SirolimusEluting Stent Versus Bare-Metal Stent in Acute Myocardial Infarction (SESAMI). J Am Coll Cardiol. 2007;49(19):1924-1930.

42. Violini R, Musto C, De Felice F, et al. Maintenance of long-term clinical benefit with sirolimus-eluting stents in patients with ST-segment elevation myocardial infarction 3-year results of the SESAMI (sirolimus-eluting stent versus bare-metal stent in acute myocardial infarction) trial. J Am Coll Cardiol. 2010;55(8):810-814.

43. Valgimigli M, Percoco G, Malagutti P, et al. Tirofiban and sirolimuseluting stent vs abciximab and bare-metal stent for acute myocardial infarction: a randomized trial. JAMA. 2005;293(17):2109-2117.
44. Tebaldi M, Arcozzi C, Campo G, et al. The 5-year clinical outcomes after a randomized comparison of sirolimus-eluting versus bare-metal stent implantation in patients with ST-segment elevation myocardial infarction. J Am Coll Cardiol. 2009;54(20):1900-1901.

45. Spaulding $C$, Henry $P$, Teiger E, et al. Sirolimus-eluting versus uncoated stents in acute myocardial infarction. $N$ Engl J Med. 2006;355(11): 1093-1104.

46. Spaulding C, Teiger E, Commeau P, et al. Four-year follow-up of TYPHOON (trial to assess the use of the CYPHer sirolimus-eluting coronary stent in acute myocardial infarction treated with BallOON angioplasty). JACC Cardiovasc Interv. 2011;4(1):14-23.

47. Rubartelli P, Petronio AS, Guiducci V, et al. Comparison of sirolimuseluting and bare metal stent for treatment of patients with total coronary occlusions: results of the GISSOC II-GISE multicentre randomized trial. Eur Heart J. 2010;31(16):2014-2020.

48. Vermeersch P, Agostoni P, Verheye S, et al. Randomized doubleblind comparison of sirolimus-eluting stent versus bare-metal stent implantation in diseased saphenous vein grafts: six-month angiographic, intravascular ultrasound, and clinical follow-up of the RRISC Trial. J Am Coll Cardiol. 2006;48(12):2423-2431.

49. Vermeersch $\mathrm{P}$, Agostoni $\mathrm{P}$, Verheye $\mathrm{S}$, et al. Increased late mortality after sirolimus-eluting stents versus bare-metal stents in diseased saphenous vein grafts: results from the randomized DELAYED RRISC Trial. $J A m$ Coll Cardiol. 2007;50(3):261-267.

50. Hakeem A, Helmy T, Leesar M, Arif I. Drug-eluting stents for saphenous vein graft lesions. JACC Cardiovasc Interv. 2011;4(5):590; author reply 591-593.

51. Mehilli J, Richard G, Neumann FJ, et al. Is Drug-Eluting Stenting Associated With Improved Results in Coronary Artery Bypass Grafts (ISAR CABG) trial. Presented at American College of Cardiology Scientific Sessions; April 3-5, 2010; New Orleans, LA.

52. Grube E, Silber S, Hauptmann KE, et al. TAXUS I: six- and twelvemonth results from a randomized, double-blind trial on a slow-release paclitaxel-eluting stent for de novo coronary lesions. Circulation. 2003; 107(1):38-42.

53. Grube E, Dawkins K, Guagliumi G, et al. TAXUS VI final 5-year results: a multicentre, randomised trial comparing polymer-based moderaterelease paclitaxel-eluting stent with a bare metal stent for treatment of long, complex coronary artery lesions. EuroIntervention. 2009;4(5): 572-577.

54. Silber S, Colombo A, Banning AP, et al. Final 5-year results of the TAXUS II trial: a randomized study to assess the effectiveness of slow- and moderate-release polymer-based paclitaxel-eluting stents for de novo coronary artery lesions. Circulation. 2009;120(15): 1498-1504.

55. Colombo A, Drzewiecki J, Banning A, et al. Randomized study to assess the effectiveness of slow- and moderate-release polymer-based paclitaxel-eluting stents for coronary artery lesions. Circulation. 2003; 108(7):788-794.

56. Stone GW, Ellis SG, Cox DA, et al. A polymer-based, paclitaxel-eluting stent in patients with coronary artery disease. $N$ Engl J Med. 2004; 350(3):221-231.

57. Stone GW, Ellis SG, Cannon L, et al. Comparison of a polymer-based paclitaxel-eluting stent with a bare metal stent in patients with complex coronary artery disease: a randomized controlled trial. JAMA. 2005; 294(10):1215-1223.

58. Ellis SG, Stone GW, Cox DA, et al. Long-term safety and efficacy with paclitaxel-eluting stents: 5-year final results of the TAXUS IV clinical trial (TAXUS IV-SR: Treatment of De Novo Coronary Disease Using a Single Paclitaxel-Eluting Stent). JACC Cardiovasc Interv. 2009;2(12): $1248-1259$.

59. Dawkins KD, Grube E, Guagliumi G, et al. Clinical efficacy of polymer-based paclitaxel-eluting stents in the treatment of complex, long coronary artery lesions from a multicenter, randomized trial: support for the use of drug-eluting stents in contemporary clinical practice. Circulation. 2005;112(21):3306-3313. 
60. Stone GW, Lansky AJ, Pocock SJ, et al. Paclitaxel-eluting stents versus bare-metal stents in acute myocardial infarction. N Engl J Med. 2009; 360(19):1946-1959.

61. Stone GW, Ellis SG, Colombo A, et al. Long-term safety and efficacy of paclitaxel-eluting stents final 5-year analysis from the TAXUS Clinical Trial Program. JACC Cardiovasc Interv. 2011;4(5):530-542.

62. Daemen J, Tsuchida K, Stefanini GG, et al. Two-year clinical follow-up of the unrestricted use of the paclitaxel-eluting stent compared to the sirolimuseluting stent as part of the Taxus-Stent Evaluated at Rotterdam Cardiology Hospital (T-SEARCH) registry. EuroIntervention. 2006; 2(3):330-337.

63. Morice MC, Colombo A, Meier B, et al. Sirolimus- vs paclitaxeleluting stents in de novo coronary artery lesions: the REALITY trial: a randomized controlled trial. JAMA. 2006;295(8):895-904.

64. Raber L, Wohlwend L, Wigger M, et al. Five-year clinical and angiographic outcomes of a randomized comparison of sirolimus-eluting and paclitaxel-eluting stents: results of the sirolimus-eluting versus paclitaxel-eluting stents for coronary revascularization LATE trial. Circulation. 2011;123(24):2819-2828.

65. Schomig A, Dibra A, Windecker S, et al. A meta-analysis of 16 randomized trials of sirolimus-eluting stents versus paclitaxel-eluting stents in patients with coronary artery disease. $\mathrm{J} \mathrm{Am} \mathrm{Coll} \mathrm{Cardiol.}$ 2007;50(14): 1373-1380.

66. Birkmeier KA, Kastrati A, Byrne RA, et al. Five-year clinical outcomes of sirolimus-eluting versus paclitaxel-eluting stents in high-risk patients. Catheter Cardiovasc Interv. 2011;77(4):494-501.

67. Lee SW, Park SW, Kim YH, et al. A randomized comparison of sirolimus- versus paclitaxel-eluting stent implantation in patients with diabetes mellitus. J Am Coll Cardiol. 2008;52(9):727-733.

68. Lee SW, Park SW, Kim YH, et al. A randomized comparison of sirolimus- versus paclitaxel-eluting stent implantation in patients with diabetes mellitus 2-year clinical outcomes of the DES-DIABETES trial. J Am Coll Cardiol. 2009;53(9):812-813.

69. Dibra A, Kastrati A, Mehilli J, et al. Paclitaxel-eluting or sirolimuseluting stents to prevent restenosis in diabetic patients. $N$ Engl J Med 2005;353(7):663-670.

70. Lee JH, Kim HS, Lee SW, et al. Prospective randomized comparison of sirolimus- versus paclitaxel-eluting stents for the treatment of acute ST-elevation myocardial infarction: pROSIT trial. Catheter Cardiovasc Interv. 2008;72(1):25-32.

71. Kim HS, Lee JH, Lee SW, et al. Long-term safety and efficacy of sirolimus- vs paclitaxel-eluting stent implantation for acute ST-elevation myocardial infarction: 3-year follow-up of the PROSIT trial. Int $J$ Cardiol. 2011;147(2):253-257.

72. Mehilli J, Kastrati A, Byrne RA, et al. Paclitaxel- versus sirolimuseluting stents for unprotected left main coronary artery disease. J Am Coll Cardiol. 2009;53(19):1760-1768.

73. Mehilli J, Dibra A, Kastrati A, et al. Randomized trial of paclitaxel- and sirolimus-eluting stents in small coronary vessels. Eur Heart J. 2006; 27(3):260-266.

74. Awata M, Nanto S, Uematsu M, et al. Angioscopic comparison of neointimal coverage between zotarolimus- and sirolimus-eluting stents. J Am Coll Cardiol. 2008;52(9):789-790.

75. Kim JS, Jang IK, Fan C, et al. Evaluation in 3 months duration of neointimal coverage after zotarolimus-eluting stent implantation by optical coherence tomography: the ENDEAVOR OCT trial. JACC Cardiovasc Interv. 2009;2(12):1240-1247.

76. Fajadet J, Wijns W, Laarman GJ, et al. Randomized, double-blind, multicenter study of the Endeavor zotarolimus-eluting phosphorylcholine-encapsulated stent for treatment of native coronary artery lesions: clinical and angiographic results of the ENDEAVOR II trial. Circulation. 2006;114(8):798-806.

77. Fajadet J, Wijns W, Laarman GJ, et al. Long-term follow-up of the randomised controlled trial to evaluate the safety and efficacy of the zotarolimus-eluting driver coronary stent in de novo native coronary artery lesions: five year outcomes in the ENDEAVOR II study. EuroIntervention. 2010;6(5):562-567.
78. Kandzari DE, Leon MB, Popma JJ, et al. Comparison of zotarolimuseluting and sirolimus-eluting stents in patients with native coronary artery disease: a randomized controlled trial. J Am Coll Cardiol. 2006; 48(12):2440-2447.

79. Kandzari DE, Mauri L, Popma JJ, et al. Late-term clinical outcomes with zotarolimus- and sirolimus-eluting stents. 5-year follow-up of the ENDEAVOR III (A Randomized Controlled Trial of the Medtronic Endeavor Drug [ABT-578] Eluting Coronary Stent System Versus the Cypher Sirolimus-Eluting Coronary Stent System in De Novo Native Coronary Artery Lesions). JACC Cardiovasc Interv. 2011;4(5): 543-550.

80. Leon MB, Mauri L, Popma JJ, et al. A randomized comparison of the ENDEAVOR zotarolimus-eluting stent versus the TAXUS paclitaxel-eluting stent in de novo native coronary lesions 12-month outcomes from the ENDEAVOR IV trial. J Am Coll Cardiol. 2010;55(6): 543-554.

81. Serruys PW, Ong AT, Piek JJ, et al. A randomized comparison of a durable polymer Everolimus-eluting stent with a bare metal coronary stent: The SPIRIT first trial. EuroIntervention. 2005;1(1):58-65.

82. Serruys PW, Ruygrok P, Neuzner J, et al. A randomised comparison of an everolimus-eluting coronary stent with a paclitaxel-eluting coronary stent: the SPIRIT II trial. EuroIntervention. 2006;2(3):286-294.

83. Stone GW, Midei M, Newman W, et al. Comparison of an everolimuseluting stent and a paclitaxel-eluting stent in patients with coronary artery disease: a randomized trial. JAMA. 2008;299(16):1903-1913.

84. Stone GW, Rizvi A, Newman W, et al. Everolimus-eluting versus paclitaxel-eluting stents in coronary artery disease. NEngl J Med. 2010; 362(18):1663-1674.

85. Kedhi E, Joesoef KS, McFadden E, et al. Second-generation everolimuseluting and paclitaxel-eluting stents in real-life practice (COMPARE): a randomised trial. Lancet. 2010;375(9710):201-209.

86. Park KW, Yoon JH, Kim JS, et al. Efficacy of Xience/promus versus Cypher in rEducing Late Loss after stENTing (EXCELLENT) trial: study design and rationale of a Korean multicenter prospective randomized trial. Am Heart J. 2009;157(5):811. e1-e817.

87. Serruys PW, Silber S, Garg S, et al. Comparison of zotarolimus-eluting and everolimus-eluting coronary stents. $N$ Engl J Med. 2010;363(2): 136-146.

88. Maluenda G, Lemesle G, Waksman R. A critical appraisal of the safety and efficacy of drug-eluting stents. Clin Pharmacol Ther. 2009;85(5): 474-480.

89. Nordmann AJ, Briel M, Bucher HC. Mortality in randomized controlled trials comparing drug-eluting vs. bare metal stents in coronary artery disease: a meta-analysis. Eur Heart J. 2006;27(23):2784-2814.

90. Pfisterer M, Brunner-La Rocca HP, Buser PT, et al. Late clinical events after clopidogrel discontinuation may limit the benefit of drug-eluting stents: an observational study of drug-eluting versus bare-metal stents. J Am Coll Cardiol. 2006;48(12):2584-2591.

91. Camenzind E, Steg PG, Wijns W. Stent thrombosis late after implantation of first-generation drug-eluting stents: a cause for concern. Circulation. 2007;115(11):1440-1455; discussion 1455.

92. Lagerqvist B, James SK, Stenestrand U, et al. Long-term outcomes with drug-eluting stents versus bare-metal stents in Sweden. $N$ Engl J Med. 2007;356(10):1009-1019.

93. Mauri L, Hsieh WH, Massaro JM, Ho KK, D’Agostino R, Cutlip DE. Stent thrombosis in randomized clinical trials of drug-eluting stents. N Engl J Med. 2007;356(10):1020-1029.

94. Stettler C, Wandel S, Allemann S, et al. Outcomes associated with drugeluting and bare-metal stents: a collaborative network meta-analysis. Lancet. 2007;370(9591):937-948.

95. Stone GW, Moses JW, Ellis SG, et al. Safety and efficacy of sirolimus- and paclitaxel-eluting coronary stents. N Engl J Med. 2007; 356(10):998-1008.

96. Kirtane AJ, Gupta A, Iyengar S, et al. Safety and efficacy of drug-eluting and bare metal stents: comprehensive meta-analysis of randomized trials and observational studies. Circulation. 2009; 119(25):3198-3206. 
97. Kastrati A, Dibra A, Spaulding C, et al. Meta-analysis of randomized trials on drug-eluting stents vs. bare-metal stents in patients with acute myocardial infarction. Eur Heart J. 2007;28(22):2706-2713.

98. Garg S, Serruys PW. Coronary stents: current status. JAm Coll Cardiol. 2010;56(10 Suppl):S1-S42.

99. Rivero F, Moreno R, Barreales L, et al. Lower levels of in-stent late loss are not associated with the risk of stent thrombosis in patients receiving drug-eluting stents. EuroIntervention. 2008;4(1):124-132.

100. Rasmussen K, Maeng M, Kaltoft A, et al. Efficacy and safety of zotarolimus-eluting and sirolimus-eluting coronary stents in routine clinical care (SORT OUT III): a randomised controlled superiority trial. Lancet. 2010;375(9720):1090-1099.

101. Camenzind E, Wijns W, Mauri L, et al. Rationale and design of the Patient Related OuTcomes with Endeavor versus Cypher stenting Trial (PROTECT): randomized controlled trial comparing the incidence of stent thrombosis and clinical events after sirolimus or zotarolimus drugeluting stent implantation. Am Heart J. 2009;158(6):902-909. e5.

102. Spertus JA, Salisbury AC, Jones PG, Conaway DJ, Thompson RC. Predictors of quality-of-life benefit after percutaneous coronary intervention. Circulation. 2004;110(25):3789-3794.

103. Parisi AF, Folland ED, Hartigan P. A comparison of angioplasty with medical therapy in the treatment of single-vessel coronary artery disease. Veterans Affairs ACME Investigators. N Engl J Med. 1992; 326(1):10-16.

104. Coronary angioplasty versus medical therapy for angina: the second Randomised Intervention Treatment of Angina (RITA-2) trial. RITA-2 trial participants. Lancet. 1997;350(9076):461-468.

105. Dagenais GR, Lu J, Faxon DP, et al. Effects of optimal medical treatment with or without coronary revascularization on angina and subsequent revascularizations in patients with type 2 diabetes mellitus and stable ischemic heart disease. Circulation. 2011;123(14):1492-1500.

106. Weintraub WS, Spertus JA, Kolm P, et al. Effect of PCI on quality of life in patients with stable coronary disease. $N$ Engl J Med. 2008; 359(7):677-687.

107. Seto TB, Taira DA, Berezin R, et al. Percutaneous coronary revascularization in elderly patients: impact on functional status and quality of life. Ann Intern Med. 2000;132(12):955-958.

108. Zhang Z, Kolm P, Boden WE, et al. The cost-effectiveness of percutaneous coronary intervention as a function of angina severity in patients with stable angina. Circ Cardiovasc Qual Outcomes. 2011; 4(2):172-182.
109. Kimble LP, Dunbar SB, Weintraub WS, McGuire DB, Manzo SF, Strickland OL. Symptom clusters and health-related quality of life in people with chronic stable angina. J Adv Nurs. 2011;67(5): 1000-1011.

110. Brorsson B, Bernstein SJ, Brook RH, Werko L. Quality of life of patients with chronic stable angina before and four years after coronary revascularisation compared with a normal population. Heart. 2002; 87(2):140-145.

111. Hueb WA, Bellotti G, de Oliveira SA, et al. The Medicine, Angioplasty or Surgery Study (MASS): a prospective, randomized trial of medical therapy, balloon angioplasty or bypass surgery for single proximal left anterior descending artery stenoses. J Am Coll Cardiol. 1995; 26(7):1600-1605

112. Henderson RA, Pocock SJ, Clayton TC, et al. Seven-year outcome in the RITA-2 trial: coronary angioplasty versus medical therapy. J Am Coll Cardiol. 2003;42(7):1161-1170.

113. Boden WE, O’Rourke RA, Teo KK, et al. Optimal medical therapy with or without PCI for stable coronary disease. N Engl J Med. 2007; 356(15):1503-1516.

114. TIME Investigators. Trial of invasive versus medical therapy in elderly patients with chronic symptomatic coronary-artery disease (TIME): a randomised trial. Lancet. 2001;358(9286):951-957.

115. Norris CM, Saunders LD, Ghali WA, et al. Health-related quality of life outcomes of patients with coronary artery disease treated with cardiac surgery, percutaneous coronary intervention or medical management. Can J Cardiol. 2004;20(12):1259-1266.

116. Cutlip DE, Windecker S, Mehran R, et al. Clinical end points in coronary stent trials: a case for standardized definitions. Circulation. 2007;115(17):2344-2351.

117. Hirlekar R, Patel M, Jain S, Kadam V. Drug eluting coronary artery stents. Curr Drug Deliv. 2010;7(5):421-427.

118. Moses JW, Leon MB, Popma JJ, et al; SIRIUS Investigators. Sirolimuseluting stents versus standard stents in patients with stenosis in a native coronary artery. N Engl J Med. 2003;349(14):1315-1323.

119. Suttorp MJ, Laarman GJ, Rahel BM, et al. Primary Stenting of Totally Occluded Native Coronary Arteries II (PRISON II): a randomized comparison of bare metal stent implantation with sirolimus-eluting stent implantation for the treatment of total coronary occlusions. Circulation. 2006;114(9):921-928.
Patient Related Outcome Measures

\section{Publish your work in this journal}

Patient Related Outcome Measures is an international, peer-reviewed, open access journal focusing on treatment outcomes specifically relevant to patients. All aspects of patient care are addressed within the journal and practitioners from all disciplines are invited to submit their work as well as healthcare researchers and patient support groups. Areas covered will

\section{Dovepress}

include: Quality of life scores; Patient satisfaction audits; Treatment outcomes that focus on the patient; Research into improving patient outcomes; Hypotheses of interventions to improve outcomes; Short communications that illustrate improved outcomes; Case reports or series that show an improved patient experience; Patient journey descriptions or research. 